Güzel, Ş. (2018). Implicit Leadership Concept and Reflection to Health Institutions. Journal of Healthcare Management and Leadership, (1), 27-33.

\title{
IMPLICIT LEADERSHIP CONCEPT AND REFLECTION TO HEALTHCARE INSTITUTIONS
}

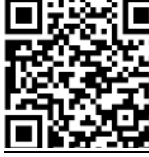

\section{ABSTRACT}

It is expressed as the person who collects the leader power, who has an impact on all processes of the organization and manages the processes. Implicit leadership emerges when other individuals in the group follow the person they want to see as the leader voluntarily (Eroğluer, 2014, p. 107).

The aim of this study is to examine the concept of implicit leadership which is not included in Turkish literature and to shed light on other studies. In addition, as in every institution, it is aimed to address the existing leadership concept in health institutions in terms of implicit leadership.

In this study, detailed information about the concept of implicit leadership was given, factors effecting the formation of implicit leadership were taken into consideration, different dimensions of implicit leadership were taken into consideration and implicit leadership was taken into consideration in terms of health institutions.

Key words: Leader, Implicit Leadership, Health Institutions

\section{INTRODUCTION}

Individuals classify those who are not leaders or non-leaders through cognitive structures according to implicit leadership theory. Therefore, the leadership prototype, which they formed in the minds of the leader as the leader by other employees, is important (Lord, Foti and De Vader, 1984, p. 344).

The implicit leadership theory, which is considered as a mental approach based on followers, refers to the qualities and behaviors that an individual expects from the leader (Kenney, Blascovich and Shaver, 1994, p. 39). Implicit leadership models are shaped by many different variables as well as personal characteristics, environment and social culture (Hunt, Boal and Sorenson, 199, p. 42).

The implicit leadership concept also plays an important role in health institutions (Karahan, 2008, p. 147). Because the expectations of the patients and the employees

"Selçuk University, Faculty of Health Science, Healthcare Management Department, serife_eren.89@hotmail.com, ORCID ID: orcid.org/0000-0002-4141-9110 
from the leader are important for health institutions where there is a human-oriented functioning (Keklik, 2012, p. 89). Therefore, the concept of implicit leadership emerges as a concept to be addressed in terms of hospitals.

In this study, it is aimed to evaluate the implicit leadership concept and to evaluate the leadership in the hospitals in terms of implicit leadership.

\section{IMPLICIT LEADERSHIP}

It is seen that leadership is handled by implicit and explicit theories. The explicit theory is based on observing and evaluating the behavior of the leader, while the implicit theory refers to the conceptual structure of leadership (Ling et al., 2000, p. 729). The implicit word indicates a mental reasoning held in memory without being expressed (Hunt, Boal, and Sorenson, 1990, p. 42). Implicit Leadership Theories are defined as cognitive structures or prototypes indicating the qualities and abilities that characterize leaders (Lord and Maher, 1991, p. 67). While explicit theories are structures of scientists based on data and scientific observations, implicit theories are considered to be the features of these people in the minds of people (Levy, Chiu, and Hong, 2006, p. 14). Hence, implicitity represents subjective reality and perceptions in contrast to scientific theories trying to approach objective reality (Sternberg, 1985, p. 607). Understanding implicit theories is considered important in terms of forming the interpretative framework in which information is processed (Chiu, Hong and Dweck, 1997, p. 20).

Especially after the 1970 s, it is noteworthy that many researchers have tried to understand how the perceptions of the leader perceive the leader rather than the characteristics and behaviors of the leader (Meindl, 1995, p. 329). The implicit leadership models, including the ideal leader prototype, lead to the classification and structure of the conceptual categories of leadership in people's minds and to classify the people they meet as leaders or not leaders (Lord, Foti Phillips, 1982, p. 109). The term (implicit al refers to a mental reasoning held in memory without being expressed (Hunt, Boal and Sorenson, 1990, p. 42). The leader and the leader can identify followers more easily and quickly than the leader or the researchers (Meindl, 1995, p. 331). In the most general sense, the phrase "cannot be a leader without his followers" refers to the starting point of the implicit leadership theory (Meindl, 1995, p. 331).

Leaders and leadership are more easily and quickly understood by implicit models in their minds than by leaders or researchers (Meindl, 1995, p. 331). There are some thoughts about the leader expression in the minds of individuals and these thoughts express implicit leadership in the characteristics and behaviors expected to be in the leader (Epitropaki et al., 2013, p. 859). Implicit leadership is thought of as a leadership style that involves ideal leaders in people's dreams (Shondrick, Dinh and Lord, 2010, p. 961). According to Türetgen and Cesur (2010), individuals determine whether or not they are leaders according to implicit leadership theories based on cognitive structures. In this respect, it is stated that implicit leadership theories are based on people's evaluations (Türetgen and Cesur, 2010, p. 52). The implicit leadership approach predicts the minds of a leader (Ling et al., 2000, p. 729). The implicit leadership states that it cannot be a leader without its followers and expresses the expectations of the followers who are kept in memory (Junker and Dink, 2014, p. 1154). 
Implicit leadership theories are used to explain leadership characteristics and perceptions, but they are seen as a possible trend in measuring true leader behavior (Den Hartog et al., 1999, p. 226). Implicit leadership theories constitute a cognitive classification in the minds of the people, "How should the ideal leader be?" For example, It is seen that people are grouped according to the characteristics of the leader with these sample patterns and whether they are leaders or not (Türetgen and Cesur, 2010, p. 52). According to Leviatan's (1975) study, one's beliefs about the behaviors and qualities a person expects from the leader is the implicit leadership theory of that person. The individual forms a model for the effective leader in his mind with the influence of many factors he encounters and lives throughout his life, and this model is expressed as an implicit leadership model (Hunt et al., 1990, p. 42). The leaders who exhibit behaviors and characteristics consistent with the implicit leadership models of the followers are seen to be more accepted within the group and direct the group (Nye and Forsyth, 1991, p. 361). Thus, leadership is expressed as the implicit interpretation of the process by the followers, including the characteristics, character, behavior and outputs of the leader (Smith and Foti, 1998, p. 148).

\subsection{Shaping Implicit Leadership}

It is seen that the implicit leadership models internalized by the individual are shaped by many different variables besides personal characteristics, environment and social culture (Hunt, Boal and Sorenson, 1990, p. 42). While implicit leadership refers to the qualities and behaviors that an individual expects from the leader (Junker and Dink, 2014, p. 1154), it is seen that an ideal leadership model is similar between the people in the same culture (Shondrick, Dinh and Lord, 2010, p. 963). The concept of leader discussed here is differentiated and shaped in line with the experience gained by people throughout life (Junker and Dink, 2014, p. 1154).

\section{Table 1. Shaping of Implicit Leadership Models}

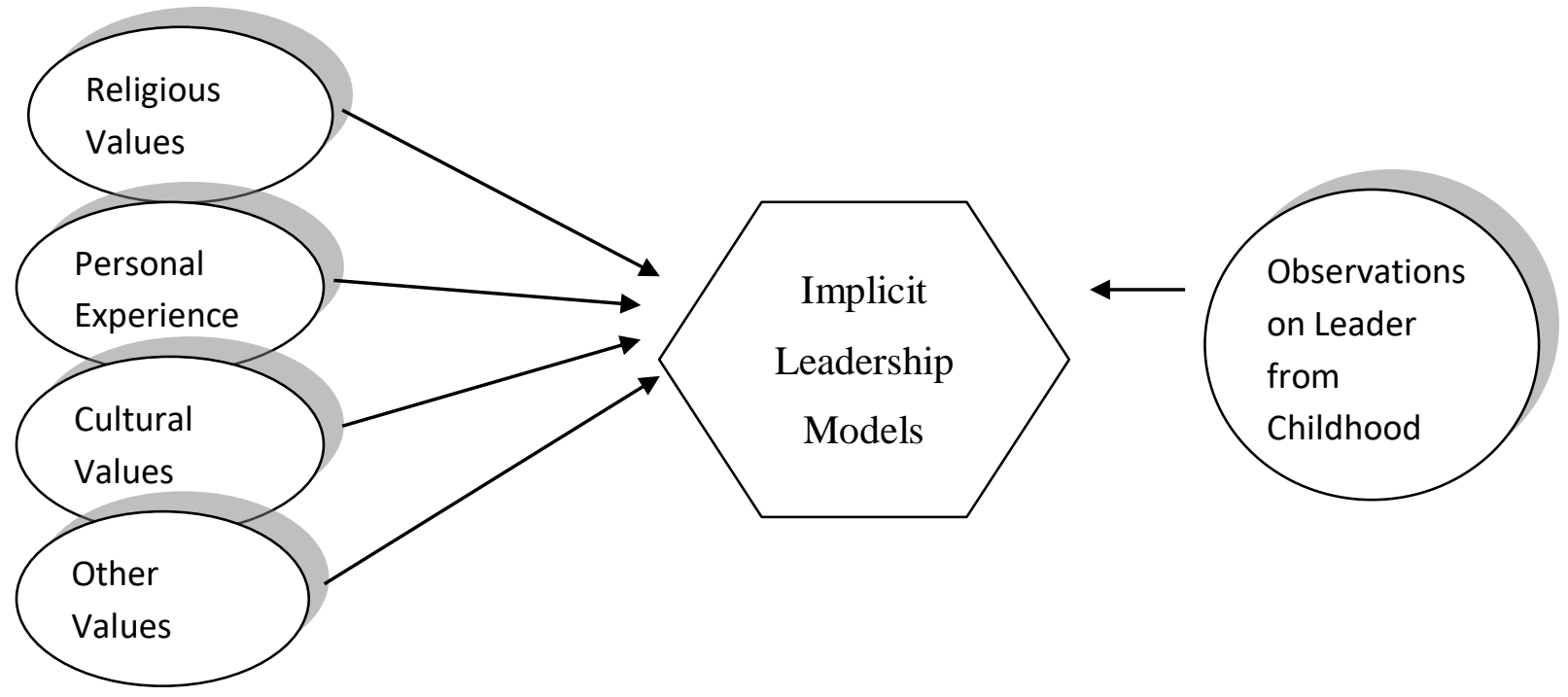

Source: Sobro, 2006, adapted from p.12. 
As can be seen in Table 1, values that determine implicit leadership include personal experiences, religious values, cultural values, as well as observations from the leader since childhood.

\subsection{Dimensioning of Implicit Leadership}

Implicit leadership has been studied in many studies in various dimensions (Lavalley, 2013, p. 28). Berber and Rofcanin (2012) in their work, implicit leadership, friendly approach of the leader, expressing the warmth of friendliness, results and expectations about the meticulous and time-expressing the disciplined dimension, team orientation, professional competency and motivation are examined in five dimensions (Berber and Rofcanin, 2012, p. 25).

The theory of implicit leadership by Offerman et al. (1994) states that it has a striking similarity with the five-factor personality trait of compatibility, openness, extraversion, neuroticism and responsibility. In addition, eight leadership dimensions are expressed as sensitivity, dedication, tyranny, charisma, attractiveness, masculinity, intelligence and strength (Keller, 1999, p. 591).

Offerman et al. (1994) according to implicit leadership theory according to the study consists of a combination of eight features. These features are seen as sensitivity, devotion, bullying, charisma, charm, masculinity, intelligence and power (Keller, 1999, p. 590).

Tabak et al. (2013) formed an implicit leadership scale suitable for Turkish culture consisting of five dimensions and 27 expressions. Determined dimensions consist of personal morality, resourcefulness, sensitivity, power and influence (Tabak et al., 2013, p. 127).

In the study, the study was conducted in the USA and Western countries, mainly in 2000 and later, and in the study of Ling, Chia and Fang (2000), it was observed that 4 factors, including personal morality, efficacy in the objectives, interpersonal skills and ability, were taken into consideration in Chinese implicit leadership models (Ling, Chia and Fang, 2000, p. 732).

Brodbeck et al., (2000) in Europe in 22 countries in the research, the notion of leadership in Europe on a cultural basis is noteworthy. In the study, European countries are divided into 5 groups in terms of cultural values and it is determined that the leader prototypes of the groups determined as a result of the investigations have changed (Brodbeck et al., 2000, p. 11).

Abdalla and Al-Homoud (2001) found no significant differences between the implicit leadership models of the people of the two countries in their research conducted in Kuwait and Qatar, but it is concluded that the Arabs prefer the motivating leadership style rather than the charismatic and autocratic leadership styles (Abdalla and AlHomoud, 2001, p. 515). 


\section{APPROACH OF IMPLICIT LEADERSHIP IN HEALTHCARE INSTITUTIONS}

As is the case in all institutions, health institutions need to be superior to the competitors and to survive in increasing competition conditions. The way to do this is through good management and leadership.

First of all, the concept of leadership is a very old concept but there are many definitions. In summary, leadership is expressed as influencing and directing the activities of others for common purposes (Koçel, 2010, p. 569; Hephill and Coons, 1957, p. 7). Leadership is vitally important for eliminating the various problems in hospitals and for the development of the hospital (Karahan, 2008, p. 147).

As healthcare institutions have a human-oriented process, how patients and employees perceive the leader and their expectations from the leader are important (Keklik, 2012, p. 89). Therefore, the concept of implicit leadership is noteworthy. According to the implicit leadership concept, there are some thoughts about the leader expression in the minds of the employees. This situation represents the ideal leadership and reveals the characteristics and behaviors expected from the leader (Eroğluer, 2014, p.113). In this context, the concept of implicit leadership is linked to the leadership approach in health institutions and according to this understanding, leaders need to act.

\section{CONCLUSION}

There are some thoughts about the leader in the minds of individuals and these thoughts are the ideal leader (Epitropaki et al., 2013, p. 859; Shondrick, Dinh and Lord, 2010, p. 961). The implicit leadership theory, which includes the ideal leader prototype, refers to the conceptual categories in the minds of people. Thus, according to these models people classify people as leaders or leaders (Lord, Foti, and De Vader, 1984, p. 344).

There are values such as personal experiences, religious values, cultural values that shape implicit leadership (Sobro, 2006, p.12). There are also many dimensions of the implicit leadership concept in the literature (Lavalley, 2013, p. 28).

If we look at the implicit leadership approach in terms of health sector, this sector is a labor intensive sector and needs good management as it is interested in human health and life. It is also considered important to determine the extent to which managers in hospitals have leadership qualities in the eyes of employees. Thus, it will be seen how health managers are perceived by the employees and it will be possible to determine the missing sides of the managers and try to correct them (Keklik, 2012, p. 75).

If there is a harmony between the implicit leadership models of the employees and the manager's behaviors, it is determined that this situation will increase job satisfaction, desire for success and work peace will be provided (Epitropaki et al., 2013, p. 867). 


\section{REFERENCES}

Abdalla, I.A. ve Al-Homoud, A.M. (2001). Exploring the Implicit Leadership Theory in the Arabian Gulf states, Applied Psychology: An International Review, 50 (4), 506-531.

Berber, A., Rofcanin, Y. (2012). Perceivers As Cognitive Misers: Scale Development For Implicit Leadershıp Theories In The Context Of MBA Degrees From Turkey, İşletme Fakültesi Dergisi. 13(1), 15-44.

Brodbeck, F.C., (2000), Cultural Variation of Leadership Prototypes Across 22 European Countries, Journal of Occupational \& Organizational Psychology, 73 (1), 1 29.

Chiu, C., Hong, Y., Dweck, C.S., (1997). Lay dispositionism and implicit theories of personality. Journal of Personality and Social Psychology, 73(1), 19.

Den Hartog, D.N., House, R.J., Hanges, P.J., (1999). Culture Specific and Crossculturally Generalizable Implicit Leadership Theories: Are Attributes of Charismatic/Transformational Leadership Universally Endorsed. Leadership Quarterly, 10(2), 219-256.

Epitropaki, O., Sy, T., Martin, R., Tram-Quon, S., Topakas, A., (2013). Implicit Leadership and Followership Theories "in the wild": Taking stock of informationprocessing approaches to leadership and followership in organizational settings, The Leadership Quarterly, 24, 858-881.

Eroğluer, K. (2014). Örtük Liderlik Üzerine Bir Analiz: İmalat Sektörü Çalışanlarının Kişilik Özelliklerinin Liderlik Algılarına Etkisi, Ege Stratejik Araştırmalar Dergisi, 5(2), 105-147.

Hemphill, J., Coons, A. (1957). Development of the Leader Behaviour Description Questionnaire, ed. R.M.Stogill- A.E. Coons, Leader Behaviour: Its Description and Measurement, Colombus: Ohio State University.

Hunt, J.G., Boal, K.B. ve Sorenson, R.L., (1990), Top Management Leadership: Inside the Black Box, Leadership Quarterly, 1, 41-65.

Junker, N.M., Dick, R., (2014). Implicit theories in organizational settings: A systematic review and research agenda of implicit leadership and followership theories, The Leadership Quarterly, 25, 1154-1173.

Karahan, A. (2008). Hastanelerde Liderlik ve Örgütsel Bağl1lık Arasındaki İlişkinin İncelenmesi, 10(1), 145-162.

Keklik, B., (2012). Sağlık Hizmetlerinde Benimsenen Liderlik Tiplerinin Belirlenmesi: Özel Bir Hastane Örneği, Afyon Kocatepe Üniversitesi, İ̇BF Dergisi, 14(1), 73-93.

Keller, T., (1999). Images of the familiar: Individual Differences and Implicit Leadership Theories, Leadership Quarterly, 10(4), 589-607. 
Kızıloğlu, A., (2011). Örtük Liderlik Kuramı Bağlamında, Sosyoekonomik Statü (Ses) Gruplarının Liderlik Algılaması, Kara Harp Okulu Savunma Bilimleri Enstitüsü, Yüksek Lisans Tezi, Ankara.

Koçel T. (2010). İşletme Yöneticiliği, Beta Yayın, İstanbul.

Lavalley, J.B., (2013). Leadership Schemas: The Influence of Organizational Context on Implicit Leadership Theories. Master of Science. Department of Psychological Sciences College of Arts and Sciences. Kansas State University.

Levy, S.R., Chui, C., Hong, Y., (2006), Lay Theories and Intergroup Relations, Group Processes and Intergroup Relations, 9(1), 5-24.

Ling, W., Chia, R.S. ve Fang, L., (2000). Chinese Implicit Leadership Theory, The Journal of Social Psychology, 140 (6), 729-739.

Lord, R.G, Foti, R.J., de Vader, R. J., (1984). A Test of Leadership Categorization Theory: Internal Structure, Information Processing, and Leadership Perceptions, Organizational Behavior and Human Performance, 34, 343-378.

Lord, R.G., Foti, R.J., ve Phillips, J.S., (1982). A Theory of Leadership Categorization, Hunt, J.G., Sekaran, U., ve Schriesheim, C.A., (Ed.), Leadership: Beyond Establishment Views, Carbondale: Southern Illinois University Pres, 104-121.

Lord, R.G., Maher, K.J., (1991). Leadership and Information Processing: Linking Perceptions and Performance, Boston, Unwin Hyman.

Meindl, J.R., (1995). The Romance of Leadership as a Follower-Centric Theory: A Social Constructionist Approach, Leadership Quarterly, 6 (3), 329-341.

Nye, J.L. ve Forsyth, D.R., (1991). The Effects of Prototype-Based Biases on Leadership Appraisals: A Test of Leadership Categorization Theory, Small Group Research, 22 (3), 360-379.

Shondrick, S.J., Dinh, J.E., Lord, R.G., (2010). Developments in implicit leadership theory and cognitive science: Applications to improving measurement and understanding alternatives to hierarchical leadership, The Leadership Quarterly, 21, 959-978.

Smith, J.A. ve Foti, R.J., (1998), A Pattern Approach to the Study of Leader Emergence, Leadership Quarterly, 9 (2), 147-160.

Sternberg, R.J., (1985), Impilicit Theories of Intelligence Creativity, and Wisdom, Journal of Personality and Social Psychology, 49(3), 607-627.

Tabak, A., Kızıloğlu A., Türköz T. (2013). Örtük Liderlik Ölçeği Geliştirme Çalışması, ODTÜ Gelişme Dergisi, 40, 97-138.

Türetgen, İ.Ö., Cesur, S., (2010). İş Yaşamındaki Yönetici Liderliğe ve Siyasi Liderliğe Yönelik Örtük Liderlik Teorilerinin Karşılaştırılması, İ.Ü. Bilimsel Araştırma Projeleri Birimi tarafından desteklenen çalışma. Proje No. BYP 3228. Yönetim Y11:21 Say1 67, 52-66. 